\title{
PERFORMA REPRODUKSI INDUK DAN PERTUMBUHAN BENIH IKAN TOR HASIL PERSILANGAN (Tor soro DAN Tor douronensis) SECARA RESIPROKAL
}

\author{
Deni Radona\#, Jojo Subagja, dan Otong Zenal Arifin \\ Balai Penelitian dan Pengembangan Budidaya Air Tawar \\ (Naskah diterima: 29 September 2014; Revisi final: 31 Agustus 2015, Disetujui publikasi: 2 September 2015)
}

\begin{abstract}
ABSTRAK
Tor merupakan jenis ikan lokal yang mempunyai nilai ekonomis tinggi tetapi belum banyak dibudidayakan. Percobaan ini bertujuan untuk membandingkan karakter reproduksi induk dan performa benih Tor soro, Tor douronensis, dan persilangannya secara resiprokal. Performa reproduksi yang diamati meliputi: derajat pembuahan (FR), derajat penetasan (HR), waktu inkubasi telur, durasi penyerapan yolk sack, panjang larva setelah yolk sack habis, dan sintasan. Parameter pertumbuhan diamati meliputi: panjang dan bobot, serta sintasan. Data hasil percobaan dianalisis menggunakan analisis varian (ANOVA), dilanjutkan uji Duncan. Hasil percobaan menunjukkan karakteristik reproduksi dari persilangan FTs x MTd memiliki nilai tertinggi pada FR $(96,88 \pm 1,67 \%)$ dan HR $(99,08 \pm 1,05 \%)$, sedangkan pada persilangan FTd x MTs memiliki nilai sintasan tertinggi $(100,00 \pm 0,00 \%)$. Analisis statistik dari karakter reproduksi hanya FR menunjukkan perbedaan yang nyata $(\mathrm{P}<0,05)$. Pertumbuhan panjang benih ikan tidak berbeda nyata dari setiap persilangan $(\mathrm{P}>0,05)$, sedangkan bobot tertinggi diperoleh pada persilangan FTs x MTd dengan nilai sebesar $1,66 \pm 0,04 \mathrm{mg}$. Heterosis rata-rata $(\mathrm{H})$ pada karakteristik reproduksi memiliki nilai positif (3,43\% pada FR; $1,04 \%$ pada $\mathrm{HR}$; dan $1,26 \%$ pada sintasan).
\end{abstract}

KATA KUNCI: Tor soro, Tor dourounensis, reproduksi, pemijahan, karakterisasi

ABSTRACT: Performance of reproductive aspects of broodstock and growth of seed of Tor soro, Tor douronensis, and their reciprocal crosses. By: Deni Radona, Jojo Subagja, and Otong Zenal Arifin

\begin{abstract}
Tor is a local fish species that have high economic value and do not widely cultivated. This experiment was aimed to compare the reproductive performance of crossed Tor soro and Tor douronensis broodstocks and growth of their reciprocal crossbred. Reproductive performance were observed such as fecundity, egg diameter, egg weight, somatic index (IOS), that latent period of spawning, fertilization rate (FR), hatching rate (HR), egg incubation time, yolk sack time, length of larvae after yolk sack exhausted, and survival. The performance observed were growth length, growth weight, and survival. The data were analyzed using analysis of variance (ANOVA), followed by Duncan test. The result showed that the reproductive performance of crossed FTs $x$ MTd resulted in highest value for the fertilization rate (FR) and hatching rate (HR) of $96.88 \pm 1.67 \%$ and $99.08 \pm 1.05 \%$, respectively statistical analysis revealed that FR was significantly different $(P<0.05)$, whereas the survival rate $(S R)$ on the cross FTd $x$ MTs amount to $100.00 \pm 0.00 \%$. The growth of length was not significantly different from each population $(P>0.05)$, whereas the highest weight was on the cross FTs $x$ MTd with value of $1.66 \pm 0.04 \mathrm{mg}$. Average heterosis $(H)$ on the reproductive characteristic have positive values: $3.34 \%$ in $F R, 1.04 \%$ on $H R$, and $1.04 \%$ in $S R$.
\end{abstract}

KEYWORDS: Tor soro, Tor douronensis, reproduction, spawning, characterization

\section{PENDAHULUAN}

Indonesia memiliki banyak ikan lokal yang berpotensi untuk dikembangkan dalam rangka meningkatkan produksi perikanan budidaya dalam mendukung industrialisasi perikanan. Salah satu komoditas

\# Korespondensi: Balai Penelitian dan Pengembangan Budidaya Air Tawar. Jl. Raya Sempur No. 1, Bogor 16154 , Indonesia. Tel.: + (0251) 8313200

E-mail: deniradona_kkp@yahoo.com yang potensial dikembangkan adalah ikan Tor. Ikan Tor merupakan ikan lokal yang tersebar di beberapa daerah di Indonesia, yakni Sumatera, Jawa, dan Kalimantan. Spesies ikan air tawar ini mempunyai nilai ekonomis penting. Populasi ikan Tor di alam tergolong langka (Wahyuningsih, 2012). Dewasa ini upaya untuk membudidayakan masih berlangsung, karena ikan ini merupakan jenis baru yang didomestikasikan dan reproduksinya belum mencapai optimal. Masalah lain yang dihadapi dewasa ini adalah bahwa 
ikan jenis Tor sebagai ikan perairan umum kurang dibudidayakan karena pertumbuhannya lambat. Siklus perkembangan dari larva sampai menjadi induk membutuhkan waktu sekitar empat tahun. Di Indonesia diketahui terdapat empat jenis ikan Tor, yaitu Tor tambroides, T. soro, T. douronensis, dan T. tambra (Haryono et al., 2009). Di dunia terdapat 20 Marga ikan Tor yang tersebar di wilayah Asia (Kiat, 2004). Ikan Tor termasuk dalam famili Cyprinidae (Kottelat et al., 1993) yang potensial dikembangkan sebagai ikan budidaya. Ikan ini sangat diminati masyarakat karena bentuknya yang bagus sebagai ikan hias.

Teknologi pembenihan ikan Tor terutama ikan Tor soro dan Tor douronensis telah berhasil dikuasai oleh para pembudidaya. Ikan Tor dengan karakter fekunditas yang tinggi memberi peluang penggunaan induk dalam jumlah yang terbatas, namun untuk memacu produksi tentunya harus mempunyai stok induk yang banyak. Dunham (2004) menyatakan ikan yang berasal dari lokasi yang berbeda mempunyai karakteristik reproduksi yang berbeda karena adanya pengaruh interaksi antara genetik dan lingkungannya. Karakteristik reproduksi masing-masing jenis diduga akan mempunyai potensi keunggulan yang berbeda. Evaluasi karakteristik reproduksi diperlukan untuk mengetahui potensi keunggulan biologis dari masing-masing populasi.

Dalam usaha meningkatkan produksi perlu adanya kajian lebih lanjut dalam menghasilkan benih yang berkualitas. Salah satu di antaranya dengan melakukan hibridisasi. Hibridisasi adalah persilangan antara dua spesies yang berbeda untuk mendapatkan keturunan yang lebih baik, yang mempunyai keunggulan pertumbuhan dari tetuanya (Tave, 1993). Menurut Horstgen-Schwark \& Langholz (1998); Uraiwan (1988), bahwa hasil hibridisasi akan memengaruhi nilai karakter reproduksi induk dalam menghasilkan kualitas benih. Beberapa penelitian terdahulu menyebutkan bahwa ada korelasi negatif antara reproduksi dan pertumbuhan (Setijaningsih et al., 2006). Keragaan bioreproduksi yang baik akan berpengaruh pada peningkatan produksi dan efisiensi budidaya sehingga peningkatan produktivitas dapat tercapai (Widyastuti et al., 2008). Percobaan ini bertujuan un- tuk mengetahui performa benih hibrid dan benih hasil tetuanya melalui pemijahan secara terkontrol.

\section{BAHAN DAN METODE}

\section{Ikan Uji}

Ikan uji yang digunakan dalam percobaan ini berasal dari ikan koleksi yang ada di Instalasi Penelitian Plasma Nutfah Perikanan Air Tawar Cijeruk. Induk digunakan sebanyak delapan ekor dari setiap populasi dengan ukuran Tor soro $(34 \pm 1,0 \mathrm{~cm}$ dan $643 \pm 20 \mathrm{~g}$ ) dan Tor douronensis (30 $\pm 1,0 \mathrm{~cm}$ dan $583 \pm 15 \mathrm{~g})$. Ikan diseleksi dengan metode kanulasi. Sebanyak dua ekor induk betina terpilih dari setiap populasi dengan masing-masing ukuran: Tor soro (33 dan $35 \mathrm{~cm}, 650$ dan $660 \mathrm{~g}$ ) dan Tor douronensis ( $31 \mathrm{dan} 29 \mathrm{~cm}, 600$ dan $580 \mathrm{~g}$ ). Sampel ikan berasal dari satu kelompok umur yang sama dan dipelihara dalam lingkungan yang sama.

\section{Proses Pemijahan}

Pematangan gonad induk dilakukan dengan memberi pakan komersial dengan kandungan protein $28 \%$ sebanyak $3 \%$ dari bobot ikan dengan frekuensi tiga kali sehari. Ikan dipelihara dalam kolam beton dengan luasan $5 \mathrm{~m} \times 2 \mathrm{~m} \times 1 \mathrm{~m}$, dengan dasar kolam terdiri atas lapisan pasir dan batu koral, serta mendapatkan pasokan air sumber dengan debit 300$450 \mathrm{~L} /$ menit. Induksi ovulasi dilakukan menggunakan rangsangan hormon HCG dan ovaprim. Hormon yang digunakan sebagai perangsang pematangan gonad adalah HCG $500 \mathrm{IU} / \mathrm{kg}$, dan setelah 24 jam induk disuntik dengan ovaprim dengan dosis $0,8 \mathrm{~mL} / \mathrm{kg}$ sebagai pemacu ovulasi (Kristanto et al., 2007; Asih et al., 2004; Sulhi et al., 2004; Legendre, 1986). Untuk memproduksi benih dilakukan persilangan secara resiprokal. Skema persilangan disajikan pada Tabel 1.

\section{Karakteristik Reproduksi}

Parameter yang diamati adalah derajat pembuahan (\%), derajat penetasan (\%), waktu inkubasi telur (hari), durasi penyerapan yolk sack (hari), panjang larva setelah yolk sack habis (cm), dan sintasan (\%). Sebanyak 150 butir telur ditebar ke dalam akuarium berukuran $20 \mathrm{~cm} \times 20 \mathrm{~cm} \times 15 \mathrm{~cm}$ dengan ketinggian air sekitar $10 \mathrm{~cm}$. Setiap akuarium diberi aerasi.

Tabel 1. Skema persilangan resiprok antara ikan Tor soro dan Tor douronensis

Table 1. Schematic cross of Tor (Tor soro and Tor douronensis) in both direction (resiprocal)

\begin{tabular}{cccc}
\hline \multirow{2}{*}{ Populasi (Population) } & \multicolumn{2}{c}{ Jantan (Male) } \\
\cline { 2 - 3 } Betina (Female) & Tor soro & Tor soro & Tor douronensis \\
\cline { 2 - 3 } & Tor douronensis & Tor douronensis $\times$ Tor soro & Tor douronensis x Tor douronensis \\
\hline
\end{tabular}


Akuarium yang digunakan sebanyak 12 buah, mewakili dari empat percobaan dan tiga ulangan. Sebagai data dukung dilakukan pengamatan kualitas air selama percobaan berlangsung meliputi: $\mathrm{pH}$, DO, suhu, nitrat, nitrit, alkalinitas, kesadahan, dan total organic matter (TOM). Parameter reproduksi yang diamati diukur menggunakan rumus menurut Effendie (1979) dan Murtidjo (2001).

\section{Pertumbuhan}

Parameter pertumbuhan yang diamati meliputi: pertumbuhan panjang $(\mathrm{cm})$, bobot $(\mathrm{g})$, dan sebagai penunjang diukur sintasannya (\%). Percobaan menggunakan 12 buah akuarium berukuran $40 \mathrm{~cm}$ x $30 \mathrm{~cm}$ x $30 \mathrm{~cm}$ dengan ketinggian air berkisar $20 \mathrm{~cm}$, masing-masing akuarium diberi aerasi dengan intensitas yang sama. Setiap akuarium ditebar larva ikan Tor sebanyak 80 ekor. Ikan Tor yang digunakan berupa larva setelah habis kuning telur (yolk sack) dari populasi hasil pemijahan: (A) FTd $x$ MTs, (B) FTs $x$ MTs, (C) FTs x MTd, dan (D) FTd x MTd ( F = female, $\mathrm{M}=$ male, $\mathrm{Ts}=$ Tor soro, dan $\mathrm{Td}=$ Tor douronensis $)$. Masing-masing perlakuan mempunyai tiga ulangan. Selama sepuluh hari pemeliharaan, ikan diberi pakan berupa Artemia secara ad-libitum dengan frekuensi dua kali sehari. Kematian ikan diamati setiap hari. Panjang standar dan bobot individu ikan uji diukur pada akhir percobaan.

\section{Nilai Heterosis}

Nilai heterosis dihitung berdasarkan persamaan Tave (1993). Nilai heterosis merupakan nilai yang menggambarkan kenaikan parameter yang diukur dari hasil hibrida dibandingkan dengan galur murninya.

$$
\mathrm{H}=\frac{\{(\mathrm{AB}+\mathrm{BA}) / 2\}-\{(\mathrm{AA}+\mathrm{BB}) / 2\}}{(\mathrm{AA}+\mathrm{BB}) / 2} \times 100 \%
$$

di mana:

$\mathrm{H}=$ Heterosis rata-rata (\%)

$\mathrm{BA}=$ Parameter terukur hasil perkawinan FTs $\mathrm{x}$ MTd

$\mathrm{AB}=$ Parameter terukur hasil perkawinan FTd $\mathrm{x}$ MTs

$\mathrm{AA}=$ Parameter terukur hasil perkawinan FTs $\mathrm{x}$ MTs

$\mathrm{BB}=$ Parameter terukur hasil perkawinan FTd $\mathrm{x}$ MTd

Untuk perhitungan heterosis sebagian/parsial pada setiap perkawinan maka digunakan rumus sebagai berikut:

$$
\mathrm{H}_{\mathrm{ba}}=\frac{\mathrm{BA}-\{(\mathrm{AA}+\mathrm{BB}) / 2\}}{(\mathrm{AA}+\mathrm{BB}) / 2} \times 100 \%
$$

di mana:

$\mathrm{H}_{\mathrm{ba}}=$ Heterosis pada hasil perkawinan FTs $\mathrm{x}$ MTd (\%)

$\mathrm{BA}=$ Parameter terukur hasil perkawinan FTs $\mathrm{x}$ MTd

$\mathrm{AA}=$ Parameter terukur hasil perkawinan FTs $\mathrm{x}$ MTs

$\mathrm{BB}=$ Parameter terukur hasil perkawinan FTd $\mathrm{x}$ MTd atau dengan rumus:

$$
\mathrm{H}_{\mathrm{ab}}=\frac{\mathrm{AB}-\{(\mathrm{AA}+\mathrm{BB}) / 2\}}{(\mathrm{AA}+\mathrm{BB}) / 2} \times 100 \%
$$

di mana:

$\mathrm{H}_{\mathrm{ab}}=$ Heterosis pada hasil perkawinan FTd $\mathrm{x}$ MTs (\%)

$\mathrm{AB}=$ Parameter terukur hasil perkawinan FTd $\mathrm{x}$ MTs

$\mathrm{AA}=$ Parameter terukur hasil perkawinan FTs $\mathrm{x}$ MTs

$\mathrm{BB}=$ Parameter terukur hasil perkawinan FTd $\mathrm{x}$ MTd

\section{Analisis Data}

Pengaruh perlakuan terhadap parameter uji dianalisis menggunakan analisis varian (ANOVA) pada selang kepercayaan 0,05 . Jika terjadi pengaruh perlakuan, dilakukan uji lanjut menggunakan uji Duncan dengan software SPSS versi 18. Data disajikan dalam bentuk tabel.

\section{HASIL DAN BAHASAN}

\section{Reproduksi}

Karakteristik reproduksi ikan Tor (soro dan douronensis) yang meliputi: panjang standar, bobot, fekunditas, somatik indeks, waktu laten pemijahan, laju pembuahan, laju penetasan, waktu inkubasi telur, durasi penyerapan yolk sack, panjang larva, dan sintasan disajikan pada Tabel 2 dan 3.

Hasil pengamatan pada induk bisa disimpulkan bahwa secara morfologi induk ikan Tor soro lebih besar $10 \%$ pada karakter bobot dan $13 \%$ pada karakter panjang bila dibandingkan dengan induk ikan Tor douronensis (Gambar 1).

Walaupun ukuran induk ikan Tor douronensis lebih kecil namun memiliki nilai fekunditas yang tinggi sebesar 4.085 butir/kg dan 4.161 butir/kg dengan diameter telur $(2,8 \pm 0,35 \mathrm{~mm})$, sedangkan induk ikan Tor soro hanya memiliki nilai fekunditas sebesar 2.063 butir $/ \mathrm{kg}$ dan 2.218 butir $/ \mathrm{kg}$ dengan diameter telur $(3,1 \pm 0,42 \mathrm{~mm})$. Nilai fekunditas tersebut tergolong tinggi bila dibandingkan dengan penelitian Gaffar et al. (1991) terhadap ikan Tor douronensis di Sumatera Selatan yang mencatat $2.073 \mathrm{butir} / \mathrm{kg}$. Menurut Bromage et al. (1993), faktor penting yang berpengaruh terhadap telur (jumlah dan ukuran) adalah ukuran dari induk yang digunakan. Semakin besar/bobot ukuran induk akan semakin meningkatkan nilai fekunditasnya. Secara total jumlah telur yang dihasilkan ini juga seirama dengan keragaman genetik dari masing-masing induk. Menurut Lagler et al. (1962), bahwa jumlah telur yang diproduksi oleh induk betina sangat dipengaruhi oleh umur induk (muda), ukuran (besar), dan kondisi ikan (segar). Selain itu, kualitas telur juga bisa dilihat dari indeks somatik (IOS). Semakin tinggi IOS, maka kualitas telur yang 
Tabel 2. Karakteristik reproduksi induk ikan Tor soro dan Tor douronensis

Table 2. Characterization of the reproductive performance of Tor soro and Tor douronensis broodstocks

\begin{tabular}{lcc}
\hline \multirow{2}{*}{$\begin{array}{c}\text { Karakteristik reproduksi induk } \\
\text { Reproduction characteristic of broodstock }\end{array}$} & \multicolumn{2}{c}{ Spesies ikan (Fish species ) } \\
\cline { 2 - 3 } & Tor soro & $\begin{array}{c}\text { Semah } \\
\text { Tor douronensis }\end{array}$ \\
\hline Panjang standar induk (Standard length) $(\mathrm{cm})$ & $34 \& 35$ & $30 \& 31$ \\
Bobot induk (Body weight) $(\mathrm{g})$ & $650 \& 660$ & $580 \& 600$ \\
Fekunditas (telur/kg) (Fecundity (eggs/kg)) & $2,063 \& 2,218$ & $4,085 \& 4,161$ \\
Diameter telur (Egg diameter) (mm) & $2.7-3.5$ & $2.4-3.2$ \\
Indeks somatik (Somatic index) (\%) & $12.5 \& 12.3$ & $12.0 \& 11.8$ \\
Waktu laten pemijahan (jam) & $14 \& 17$ & $15 \& 17$ \\
Latent period of spawning (hour) & & \\
\hline
\end{tabular}

Tabel 3. Karakteristik reproduksi hasil pemijahan induk ikan Tor soro, Tor douronensis, dan persilangannya Table 3. Characterization of the parent spawning fish reproduction result Tor soro, Tor douronensis, and crossing

\begin{tabular}{|c|c|c|c|c|}
\hline \multirow{2}{*}{$\begin{array}{c}\text { Karakter reproduksi } \\
\text { Characterization reproduction }\end{array}$} & \multicolumn{4}{|c|}{$\begin{array}{l}\text { Skema pemijahan secara resiprokal } \\
\text { Reciprocal spawning scheme }\end{array}$} \\
\hline & FTs $\mathrm{x}$ MTs & FTd $x$ MTd & FTs $x$ MTd & FTd $x$ MTs \\
\hline Derajat pembuahan (Fertilization rate) $(\%)$ & $93.77 \pm 1.01^{\mathrm{c}}$ & $81.11 \pm 1.01^{\mathrm{a}}$ & $96.88 \pm 1.67^{\mathrm{d}}$ & $84.00 \pm 2.00^{\mathrm{b}}$ \\
\hline Derajat penetasan (Hatching rate) $(\%)$ & $96.67 \pm 0.4^{\mathrm{a}}$ & $96.44 \pm 3.29^{\mathrm{a}}$ & $99.08 \pm 1.05^{\mathrm{a}}$ & $96.04 \pm 1.52^{\mathrm{a}}$ \\
\hline $\begin{array}{l}\text { Waktu inkubasi telur (hari) } \\
\text { Egg incubation time (days after fertilization) }\end{array}$ & $6 \pm 0^{b}$ & $6 \pm 0^{b}$ & $7 \pm 0^{c}$ & $3 \pm 0^{\mathrm{a}}$ \\
\hline $\begin{array}{l}\text { Durasi penyerapan yolk sack (hari) } \\
\text { Period of yolk sack (day) }\end{array}$ & $6 \pm 0^{c}$ & $4 \pm 0^{\mathrm{a}}$ & $5 \pm 0^{b}$ & $7 \pm 0^{d}$ \\
\hline Panjang larva (Larvae length $)(\mathrm{cm})$ & $1.16 \pm 0.04^{\mathrm{b}}$ & $1.02 \pm 0.06^{\mathrm{a}}$ & $1.12 \pm 0.05^{\mathrm{b}}$ & $1.08 \pm 0.04^{\mathrm{b}}$ \\
\hline Sintasan (Survival rate) $(\%)$ & $99.75 \pm 0.42^{b}$ & $96.84 \pm 1.85^{\mathrm{a}}$ & $99.07 \pm 0.40^{\mathrm{b}}$ & $100.00 \pm 0.00^{\mathrm{b}}$ \\
\hline
\end{tabular}

Keterangan (Note):

$\mathrm{F}=$ Betina (Female), $\mathrm{M}=$ Jantan (Male), $\mathrm{Ts}=$ Tor soro, dan (and) $\mathrm{Td}=$ Tor douronensis

Angka yang diikuti huruf superskrip yang berbeda pada lajur yang sama menunjukkan berbeda nyata $(\mathrm{P}<0,05)($ Numbers followed by the same in his column indicates no significant difference $(P<0.05))$

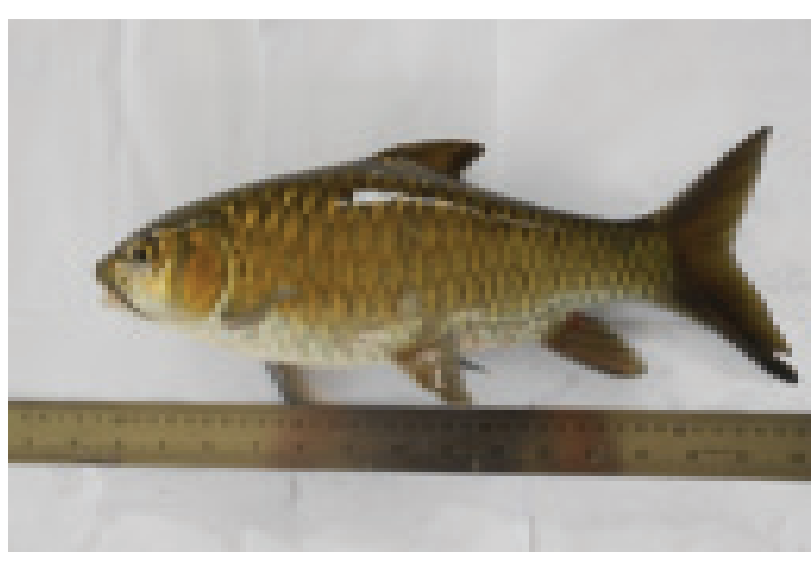

Tor douronensis betina (Female)

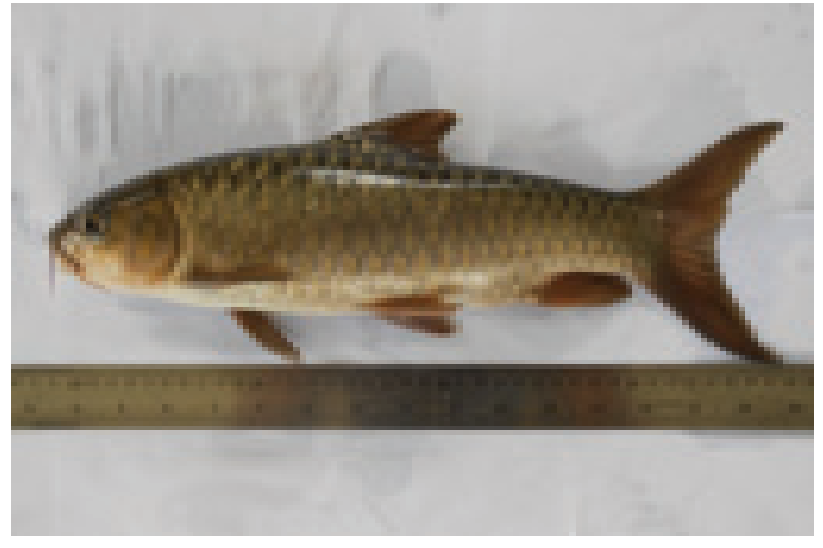

Tor soro betina (Female)

Gambar 1. Induk ikan Tor yang digunakan dalam proses perkawinan silang

Figure 1. Tor parent fish used in crosses breeding 
dihasilkan juga semakin bagus. IOS tertinggi pada percobaan ini adalah pada induk ikan Tor soro sebesar 12,5\% dan 12,3\%; sedangkan IOS pada induk ikan Tor douronensis sebesar 12,0\% dan 11,8\%. Dilihat dari karakter waktu laten pemijahan dari kedua jenis induk Tor (soro dan douronensis) tidak ditemukan selisih waktu yang berbeda. Dari data di atas bisa disimpulkan bahwa karakter reproduksi sebelum terjadi proses pembuahan dari kedua jenis induk terdapat perbedaan yang nyata.

Karakteristik reproduksi setelah pembuahan dari kedua jenis ikan Tor (soro dan douronensis) pada parameter yang diamati terlihat berbeda $(\mathrm{P}<0,05)$ dalam hal karakteristik derajat pembuahan (FR), lama penetasan, dan durasi penyerapan yolk sack (Tabel 3). Untuk panjang larva $(\mathrm{cm})$ dan sintasan dari setiap persilangan tidak terlihat ada perbedaan $(\mathrm{P}>0,05)$. Derajat pembuahan tertinggi diperoleh pada persilangan FTs x MTd sebesar 96,88 $\pm 1,67 \%$; sedangkan pada persilangan FTd x MTs hanya memiliki nilai $84,00 \pm 2,00 \%$. Karakteristik reproduksi tersebut tidak lebih baik dari derajat pembuahan hasil pemija-

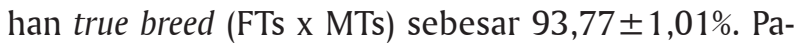
da karakter derajat penetasan (HR), persilangan FTs $x$ MTd memiliki nilai tertinggi sebesar 99,08 $\pm 1,05 \%$ bila dibandingkan persilangan FTd x MTs dengan nilai 96,04 $\pm 1,52 \%$; memberikan hasil yang nyata pada waktu inkubasi telur dan durasi penyerapan yolk sack dengan penetasan tercepat (tiga hari) dan kandungan yolk sack terlama (tujuh hari).

Nilai panjang larva dan sintasan dari setiap populasi hasil persilangan tidak menunjukkan perbedaan dengan nilai panjang larva terbesar $(1,16 \pm 0,04 \mathrm{~cm})$ pada pemijahan true breed FTs x MTs dan terkecil $(1,08 \pm 0,04 \mathrm{~cm})$ pada persilangan FTd $x$ MTs sedangkan nilai sintasan tertinggi dihasilkan dari persilangan FTd x MTs sebesar 100,00 $\pm 0,00 \%$. Derajat pembuahan dan penetasan telur digunakan sebagai ukuran kualitas telur yang dihasilkan dari masing-masing induk. Laju pembuahan telur dievaluasi dari warna telur setelah 24 jam telur dipijahkan. Telur yang dibuahi akan berwarna kuning cerah, sedangkan yang tidak dibuahi akan berwarna kuning keputih-putihan
(Setijaningsih et al., 2006). Menurut Falconer (1983), sifat fenotipe dari suatu organisme dipengaruhi oleh tiga faktor: genotipe, lingkungan, dan interaksi keduanya. Karena lingkungan untuk penetasan telur mempunyai kondisi yang tidak berbeda, maka dapat diduga bahwa kemampuan daya tetas telur ini sebagian besar merupakan sifat yang diwariskan. Hasil penelitian memperlihatkan bahwa produksi telur setiap induk betina sangat bervariasi bergantung pada jenis ikan yang dicoba.

\section{Nilai Heterosis pada Karakter Bioreproduksi}

Nilai heterosis merupakan indikasi keberhasilan program hibridisasi. Nilai heterosis karakter reproduksi pada persilangan ikan Tor (soro dan douronensis) yang meliputi: derajat pembuahan, derajat penetasan, dan sintasan disajikan pada Tabel 4.

Pengamatan derajat pembuahan dilakukan $(2 \pm 1$ jam) setelah telur dibuahi, diperoleh nilai heterosis (H) secara rata-rata sebesar 3,43\%. Nilai heterosis yang dihasilkan pada FTs x MTd mempunyai nilai positif sebesar 10,79\% dan heterosis yang dihasilkan pada FTd x MTs mempunyai nilai $-3,93 \%$. Hal ini menunjukkan bahwa persilangan antara FTs x MTd berpengaruh terhadap derajat pembuahan. Pengamatan derajat penetasan dilakukan terhadap telur yang menetas $(5 \pm 1$ hari), diperoleh nilai heterosis $(\mathrm{H})$ secara rata-rata sebesar $1,04 \%$. Heterosis yang dihasilkan pada FTs x MTd mempunyai nilai positif sebesar 2,61\% dan heterosis yang dihasilkan pada FTd x MTs mempunyai nilai $-0,53 \%$. Walaupun relatif kecil, keadaan ini memberikan informasi bahwa perbaikan derajat pembuahan masih dapat ditingkatkan.

Pengamatan sintasan dilakukan terhadap larva yang bertahan hidup sampai yolk sack habis. Nilai heterosis $(\mathrm{H})$ sintasan secara rata-rata sebesar $1,26 \%$. Heterosis yang dihasilkan pada FTs x MTd mempunyai nilai positif sebesar $0,78 \%$ dan heterosis yang dihasilkan pada FTd x MTs mempunyai nilai 1,73\%. Rendahnya nilai heterosis bukan berarti keturunan hasil persilangan jelek tetapi lebih menerangkan atau menggambarkan suatu kondisi perbandingan antara rata-rata keturunan dengan rata-rata kedua tetuanya

Tabel 4. Nilai heterosis performa reproduksi pada persilangan Tor soro dan Tor douronensis Table 4. Heterosis value of reproductive performance in crossbred of Tor soro and Tor douronensis

\begin{tabular}{lcc}
\hline \multirow{2}{*}{$\begin{array}{c}\text { Karakter reproduksi } \\
\text { Characterization reproduction }\end{array}$} & \multicolumn{2}{c}{ Nilai heterosis (Heterosis value) (\%) } \\
\cline { 2 - 3 } & FTd x MTs & FTs x MTd \\
\hline Derajat pembuahan (Fertilization rate) & -3.93 & 10.79 \\
Derajat penetasan (Hatching rate) & -0.53 & 2.61 \\
Sintasan (Survival rate) & 1.73 & 0.78 \\
\hline
\end{tabular}


(Nugroho, 2010). Persilangan antara Tor soro dengan Tor douronensis (dua arah) tidak meningkatkan secara signifikan terhadap sintasan.

\section{Pertumbuhan Benih Ikan Tor}

Pertumbuhan merupakan faktor yang penting pada makhluk hidup. Pertumbuhan bobot dan panjang benih ikan Tor dari setiap populasi hasil pemijahan secara resiprokal selama percobaan disajikan pada Tabel 5, sedangkan sintasan disajikan pada Gambar 2.

Berdasarkan pengamatan pada karakter pertumbuhan (Tabel 5), untuk hasil persilangan diperoleh nilai pertambahan panjang tertinggi pada persilangan FTs x MTd sebesar 0,10 $0,03 \mathrm{~cm}$ sedangkan pada persilangan FTd x MTs hanya $0,04 \pm 0,03 \mathrm{~cm}$. Nilai pertambahan panjang tersebut memang jauh dari nilai pertambahan yang dihasilkan oleh pemijahan true breed (FTs x MTs) yang memiliki nilai pertambahan panjang sebesar $0,15 \pm 0,03 \mathrm{~cm}$. Nilai tersebut besar dikarenakan karakter panjang larva awal ikan Tor soro yang memang besar $(1,16 \pm 0,04 \mathrm{~cm})$ bila dibandingkan dengan panjang larva awal ikan Tor douronensis yang hanya memiliki panjang $(1,02 \pm 0,06 \mathrm{~cm})$. Hasil uji statistik menunjukkan bahwa nilai pertambahan panjang yang dihasilkan dari persilangan FTs $\mathrm{x}$ MTd tidak berbeda dengan pertambahan panjang yang terjadi pada true breed FTs x MTs $(\mathrm{P}>0,05)$; namun berbeda $(\mathrm{P}<0,05)$ terhadap nilai pertambahan panjang yang dihasilkan dari persilangan FTd x MTs. Tidak adanya perbedaan pertambahan panjang dikarenakan induk yang digunakan berasal dari kelompok yang sama. Imron et al. (2000) rendahnya keragaman ukuran, merupakan indikasi rendahnya keragaman genetik pada karakter pertambahan bobot, memiliki nilai pertambahan bobot yang berbeda nyata $(\mathrm{P}<0,05)$ dari masing-masing populasi (FTs x MTs,
FTd x MTd) dan persilangannya (FTs x MTd dan FTd $x$ MTs) dengan nilai pertambahan bobot tertinggi pada FTs x MTd sebesar 1,66 $\pm 0,04 \mathrm{mg}$ dan terendah pada FTd x MTd sebesar 0,31 $\pm 0,06 \mathrm{mg}$.

\section{Sintasan Benih Dari Setiap Populasi}

Sintasan benih ikan Tor relatif sama antar populasi pada semua persilangan. Dari empat sumber genetik yang dihasilkan dari persilangan secara resiprokal, baik persilangan FTs x MTd maupun persilangan FTd x MTs memiliki nilai sintasan yang optimal sebesar $100 \pm 0 \%$, sedangkan dari hasil pemijahan true breed (FTs x MTs, FTd x MTd) hanya memiliki nilai sintasan masing-masing sebesar 96,6 $\pm 1,44$ dan 99,5 $\pm 0,72 \%$ (Gambar 2). Sintasan benih adalah faktor penting yang diutamakan di dalam kegiatan budidaya, dengan persilangan diharapkan nilai sintasannya meningkat. Nilai sintasan dari persilangan yang lebih tinggi jika dibanding dari tetuanya (induk) sejalan dengan pernyataan (Lemarie, 2001) yang mengatakan bahwa peningkatan heterozigositas pada perkawinan beda kerabat diduga dapat menghasilkan perbaikan dan peningkatan sintasan.

\section{Nilai Heterosis pada Karakter Pertumbuhan}

Nilai heterosis pertumbuhan panjang dan bobot, serta sintasan keempat sumber genetik yang dihasilkan dari persilangan secara resiprokal, baik persilangan true breed (FTs x MTs, FTd x MTd) maupun persilangan (FTs x MTd dan FTd x MTs) disajikan pada Tabel 6. Persilangan dapat meningkatkan performa pertumbuhan tanpa adanya efek genetik tambahan. Nilai heterosis rata-rata dari karakter pertambahan panjang, bobot, dan sintasan yang diperoleh adalah bervariasi. Nilai heterosis rata-rata pada karakter pertambahan panjang dan sintasan menunjuk-

Tabel 5. Pertambahan panjang dan bobot, serta sintasan ikan hasil pemijahan induk ikan Tor soro, Tor douronensis, dan persilangannya

Table 5. Length growth, weight growth, and survival rate fish spawning parent result Tor soro, Tor douronensis, and their reciprocal crossing

\begin{tabular}{lcccc}
\hline \multirow{2}{*}{$\begin{array}{c}\text { Parameter } \\
\text { Parameters }\end{array}$} & \multicolumn{3}{c}{ Ikan tor (Tor fish) } \\
\cline { 2 - 5 } & FTs x MTs & FTd x MTd & FTs $x$ MTd & FTd $x$ MTs \\
\hline Panjang awal (Initial length) $(\mathrm{cm})$ & $1.16 \pm 0.04^{\mathrm{c}}$ & $1.02 \pm 0.06^{\mathrm{a}}$ & $1.12 \pm 0.05^{\mathrm{b}}$ & $1.16 \pm 0.04^{\mathrm{c}}$ \\
Bobot awal (Initial body weight) (mg) & $1.83 \pm 0.02^{\mathrm{a}}$ & $0.69 \pm 0.08^{\mathrm{c}}$ & $1.34 \pm 0.02^{\mathrm{b}}$ & $1.66 \pm 0.02^{\mathrm{ab}}$ \\
Panjang akhir (Final length) $(\mathrm{cm})$ & $1.31 \pm 0.07$ & $1.10 \pm 0.08$ & $1.22 \pm 0.06$ & $1.20 \pm 0.05$ \\
Bobot akhir (Final body weight) $(\mathrm{mg})$ & $2.40 \pm 1.20$ & $1.00 \pm 0.10$ & $3.00 \pm 0.60$ & $2.70 \pm 0.10$ \\
Panjang mutlak (Absolute length) $(\mathrm{cm})$ & $0.15 \pm 0.03^{\mathrm{b}}$ & $0.08 \pm 0.04^{\mathrm{a}}$ & $0.10 \pm 0.03^{\mathrm{ab}}$ & $0.04 \pm 0.03^{\mathrm{a}}$ \\
Bobot mutlak (Absolute weight) $(\mathrm{mg})$ & $0.57 \pm 0.02^{\mathrm{b}}$ & $0.31 \pm 0.06^{\mathrm{a}}$ & $1.66 \pm 0.04^{\mathrm{d}}$ & $1.04 \pm 0.06^{\mathrm{c}}$ \\
\hline
\end{tabular}

Keterangan (Note):

Angka yang diikuti huruf superskrip yang berbeda pada lajur yang sama menunjukkan berbeda nyata $(\mathrm{P}<0,05)($ Numbers followed by the same in his column indicates no significant difference $(P<0.05))$ 


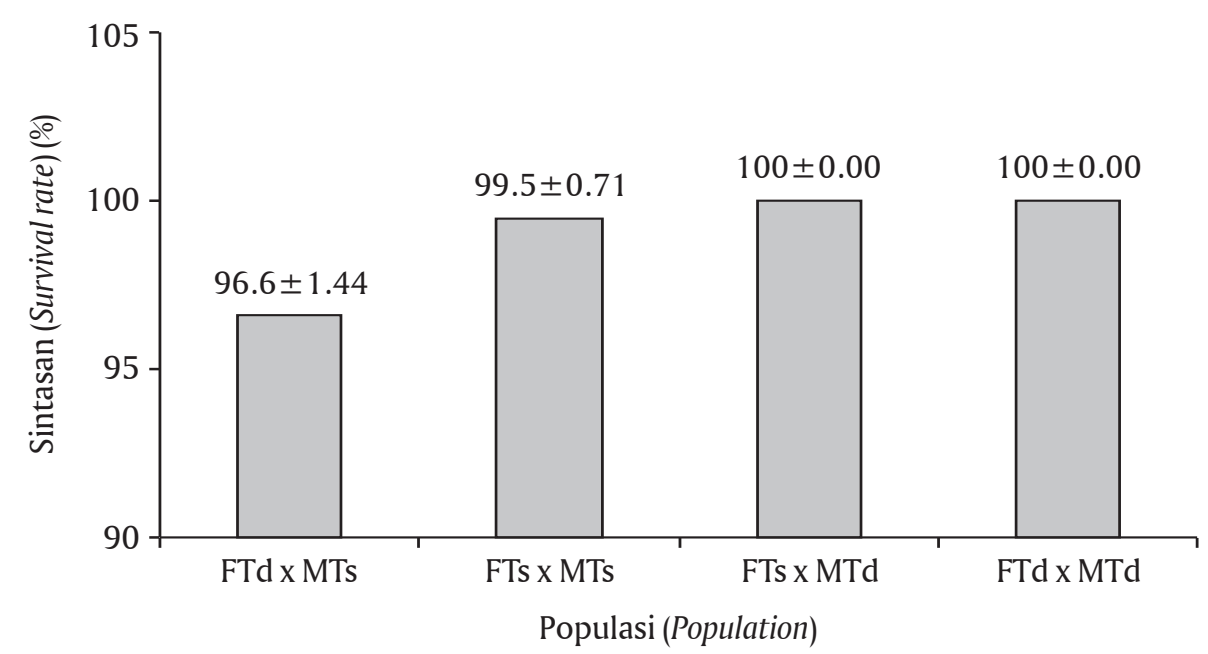

Gambar 2. Sintasan benih ikan Tor soro, Tor douronensis, dan hasil persilangannya secara resiprokal selama sepuluh hari pemeliharaan

Figure 2. Survival rate of seed of Tor soro, Tor douronensis, and their reciprocal crossed for ten days of raising

Tabel 6. Nilai heterosis karakter pertumbuhan benih hasil persilangan secara resiprokal ikan Tor soro dan Tor douronensis

Table 6. Heterosis value for growth of seed resulting from reciprocal crossing of Tor soro and Tor douronensis

\begin{tabular}{lcc}
\hline \multirow{2}{*}{$\begin{array}{c}\text { Karakter pertumbuhan } \\
\text { Character growth }\end{array}$} & \multicolumn{2}{c}{ Nilai heterosis (Heterosis value) (\%) } \\
\cline { 2 - 3 } & FTd $x$ MTs & FTs $\boldsymbol{x}$ MTd \\
\hline Pertumbuhan panjang mutlak (Absolute growth in length) & -65.21 & -13.04 \\
Pertumbuhan bobot mutlak (Absolute growth in weight) & 136 & 277.27 \\
Sintasan (Survival rate) & -3.15 & 0.25 \\
\hline
\end{tabular}

kan nilai yang negatif $(-39,13 \%$ dan $-1,45 \%)$. Namun secara parsial nilai heterosis sintasan pada persilangan FTs x MTd diperoleh nilai positif sebesar 0,25\%. Nilai heterosis menerangkan suatu kondisi perbandingan antara rata-rata keturunan dengan rata-rata kedua tetuanya (Warwick et al., 1995). Berbeda dengan karakter panjang dan sintasan, pada pertambahan bobot diperoleh nilai heterosis rata-rata yang signifikan positif sebesar 206,81\%. Dengan nilai heterosis terbesar pada persilangan FTs x MTd sebesar $277,27 \%$. Hasil penelitian Verdegem (1997) yang menyatakan persilangan beda spesies akan memperlihatkan heterosis positif pada pertumbuhan bobot. Kondisi ini sesuai dengan hasil penelitian Atabuga et al. (2010) yang mendapatkan nilai heterosis karakter bobot pada persilangan beda spesies ikan lele (Clarias gariepenus dengan Heterobranchus longifilis) sebesar $29,4 \%$.

Pemilihan sumber genetik yang tepat tentu saja akan meningkatkan kualitas fenotipe heterozigot hibridisasi. Secara genetis, persilangan mampu menambah keragaman genetik serta menyatukan keunggulan dari masing-masing spesies kepada ketu- runan hasil persilangan. Namun keragaman genetik yang tinggi belum tentu menghasilkan benih hasil persilangan dengan performa baik, hal tersebut bergantung kepada intensitas gen yang memiliki sifat keunggulan. Gen tersebut akan terekspresi secara maksimal atau tidak bergantung pada kondisi lingkungan budidaya. Potensi genetik tidak dapat terekspresi dengan baik tanpa dukungan lingkungan (Dunham, 2004).

\section{Kualitas Air}

Pengukuran kondisi perairan dilakukan untuk menunjang kegiatan karena lingkungan memengaruhi keberhasilan dalam proses budidaya. Hasil pengukuran kualitas air selama kegiatan terlihat pada Tabel 7.

Secara umum data kisaran kualitas air (suhu, pH, DO, alkalinitas, nitrat $\left(\mathrm{NO}_{3}\right)$, nitrit $\left(\mathrm{NO}_{2}\right)$, kesadahan, dan total bahan organik) yang diperoleh selama percobaan masih dalam batas toleransi (Subagja et al., 2013; Boyd, 1990; Zonneveld, 1991) untuk kematangan gonad optimum, proses pertumbuhan, serta laju sintasan larva. 
Tabel 7. Nilai kualitas air di akuarium selama percobaan

Table 7. The value of water quality in the aquarium during the experiment

\begin{tabular}{lc}
\hline $\begin{array}{l}\text { Variabel (kualitas air) } \\
\text { Variable (water quality) }\end{array}$ & $\begin{array}{c}\text { Kisaran } \\
\text { Range }\end{array}$ \\
\hline Suhu (Temperature) $\left({ }^{\circ} \mathrm{C}\right)$ & $23-26.5$ \\
$\mathrm{pH}$ & $6-7$ \\
Oksigen terlarut & $5.1-6$ \\
Dissolved oxygen $(\mathrm{mg} / \mathrm{L})$ & \\
Alkalinitas (Alkalinity) $(\mathrm{mg} / \mathrm{L})$ & $88.4-91.1$ \\
Nitrit $($ Nitrite) $(\mathrm{mg} / \mathrm{L})$ & $0.016-0.020$ \\
Nitrat $($ Nitrate) $)(\mathrm{mg} / \mathrm{L})$ & $0.76-1.44$ \\
Kesadahan $($ Hardness $)$ & $93.0-93.5$ \\
TOM (Total organic matter) & $5.01-10.02$ \\
\hline
\end{tabular}

\section{KESIMPULAN}

Persilangan FTs x MTd memberikan hasil yang positif pada peningkatan nilai derajat pembuahan dan derajat penetasan $(96,88 \pm 1,67 \%$ dan $99,08 \pm 1,05 \%)$ dengan nilai heterosis ( $10,79 \%$ dan $2,61 \%)$, sedangkan persilangan FTd x MTs memberikan dampak positif pada sintasan $(100,00 \pm 0,00)$ dengan nilai heterosis $(1,73 \%)$.

\section{UCAPAN TERIMA KASIH}

Penulis mengucapkan terima kasih kepada Sdr. Sudarmaji, Sirodiana, Heppy Haprilistianto, Ujang Heri Heryana atas bantuan teknis yang diberikan.

\section{DAFTAR ACUAN}

Asih, S., Subagja, J., Winarlin, \& Widiyati, A. (2004). Penguasaan teknik pembenihan dan pembesaran ikan Batak: peningkatan kualitas telur melalui perlakuan hormonal pada penyuntikan awal dalam berbagai dosis dan selang waktu berbeda. Laporan Hasil Penelitian Balai Riset Perikanan Budidaya Air Tawar. hlm. 314-323.

Atabuga, A.G., Annune, P.A., \& Ogbe, F.G. (2010). Growth performance of two African catfishes Clarias gariepenus and Heterobranchus longifilis and their hybrids in plastic aquaria. Aquac. res.

Boyd, C.E. (1990). Water quality in ponds for aquaculture. Chapman and Hall. New York, 454 pp.

Bromage, N., Randall, C., Duston, J., Thursh, M., \& Jones, J. (1993). Environmental control of reproduction in salmonids. In Muir, J., \& Roberts, R. (Eds.). Recent advances in aquaculture. IV. Blackwell Science. Oxford, p. 55-66.

Dunham, R.A. (2004). Aquaculture and fisheries biotechnology, genetic approaches. Cabi Publishing.
367. pp.

Effendie. M.I. (1979). Metode biologi perikanan. Yayasan Dewi Sri. Bogor.

Falconer, D.S. (1983). Introduction to quantitative genetics. $2^{\text {nd }}$ ed. Lonb'lllan, New York. USA, 438 pp.

Gaffar, A.K., Utomo, A.D., \& Adjie, S. (1991). Pola pertumbuhan, makanan dan fekunditas ikan semah (Labeobarbus douronensis) di Sungai Komering Bagian Hulu, Sumatera Selatan. Bull. Penel. Perik. Darat, 10(1), 17-22.

Haryono, A., Tjakrawaidjaja, \& Wahyudewantoro, G. (2009). Proses domestikasi dan reproduksi ikan tambra yang telah langka menuju budidayanya. Pusat Penelitian Biologi. LIPI Press, hlm. 2-15.

Horstgen-Schwark, G., \& Langholz, H.J. (1998). Prospects of selecting for late maturity in tilapia (Oreochromis niloticus) III: A selection experiments under laboratory condition. Aquaculture, 167, 123133.

Imron, Subagyo, \& Arifin, O.Z. (2000). Variabilitas truss morfometrik 4 galur ikan mas: Majalaya, Rajadanu, Wildan, dan Sutisna. Prosiding Penil. Perik. 1999. Puslitbang Perikanan. DKP, hlm. 188-197.

Kiat, Ng-Chi. (2004). The kings of the rivers mahseer in Malaysia and the region. Selangor: Inter Sea Fishery.

Kottelat, M., Whitten, A.J., Kartika Sari, S.N., \& Wirjoadmodjo, S. (1993). Freshwater fishes of Western Indonesian and Sulawesi. Periplus, Jakarta. $221 \mathrm{pp}$.

Kristanto, A.H., Asih, S., \& Winarlin. (2007). Karakterisasi reproduksi dan morfometrik ikan Batak dari dua lokasi (Sumatera Utara dan Jawa Barat). J. Ris. Akuakultur, 2(1), 59-65.

Lagler, K.F., Bardach, J.E., \& Miller, R.R. (1962). Ichthyology. Jhon Willey and Sons Inc. New York, $545 \mathrm{pp}$.

Lemarie, G. (2001). A simple test to evaluate the salinity tolerance of Oreochromis niloticus, Saotherodon melanotheron and their hybrids. IFREMER, Palavas.

Legendre, M. (1986). Seasonal changes in sexual maturity and fecundity, and HCG induced breeding of the catfish, Heterobranchus longifilis val (Claridae) Reared in Ebrie Lagoon (Ivory Coast). Aquaculture, 55, 201-213.

Murtidjo. B.A. (2001). Beberapa metode pembenihan ikan air tawar. Kanisius. Yogyakarta, $108 \mathrm{hlm}$.

Nugroho, E. (2010). Evaluasi genetik ras-ras ikan gurame dengan menggunakan marker DNA. (inpress).

Setijaningsih, L., Azwar, Z.A., Nugroho, E., \& Sulhi, M. (2006). Pengaruh suplementasi askorbil fosfat magnesium sebagai sumber vitamin $\mathrm{C}$ dalam 
pakan terhadap reproduksi induk ikan gurame (Osphronemus gouramy Lac). J. Ris. Akuakultur, 1(3), 437-445.

Subagja, J., Radona, D., Cahyanti, W., \& Asih, S. (2013). Pembenihan ikan semah (Tor douronensis. Val. 1842). Laporan teknis penelitian APBN BPPBAT Bogor. Unpublished.

Sulhi, M., Subagja, J., Asih, S., \& Nugroho, E. (2004). Perubahan musiman dan induksi pematangan gonad ikan Tor Soro (teleostei, cyprinidae) melalui implantasi pelet hormon gonadotropin mamalia (HCG). Laporan Hasil Penelitian Balai Riset Perikanan Budidaya Air Tawar. hlm. 217-226.

Tave, D. (1993). Genetics for fish managers. The AVI Publ. Comp. Inc. Ny. USA, 299 pp.

Uraiwan, S. (1988). Direct and indirect responses to selection for age maturation of Oreochromis niloticus. In Pullin et al. (Ed.). The Second International Symposium on Tilapia in Aquaculture, p. 295-300.
Verdegem, M.C.J., Hilbrands, A.D., \& Boon, J.H. (1997). Influence of salinity and dietary composition on blood parameter values of hybrids red tilapia. Aquac. Res., 28, 453-459.

Warwick, M., Astuti, W., \& Hardjosubroto. (1995). Pemuliaan ternak. Gajah Mada University Pers. Jogjakarta, $490 \mathrm{hlm}$.

Wahyuningsih, H. (2012). Induksi buatan pada perkembangan gonad ikan Tor soro. Disertasi. Fakultas Kelautan dan Perikanan IPB. Bogor.

Widyastuti, Y., Subagja, J., \& Gustiano, R. (2008). Reproduksi ikan nila (Oreochromis niloticus) seleksi dan non seleksi dengan pemijahan buatan: karakter induk, telur, embrio dan benih. Jurnal Iktiologi Indonesia, 8(1), 17-20.

Zonneveld, N., Huisman, E.A., \& Boon, J.H. (1991). Prinsip-prinsip budidaya ikan. Gramedia Pustaka Utama. Jakarta, 317 hlm. 